Volume 10 Issue 2, April-June 2016: pp. 221-412. Copyright (C) 2015-2016 FIAT JUSTISIA. Faculty of Law, Lampung University, Bandarlampung, Lampung, Indonesia.

ISSN: 1978-5186 | e-ISSN: 2477-6238.

Open Access: http://jurnal.fh.unila.ac.id/index.php/fiat

Fiat Justisia is licensed under a Creative Commons Attribution 4.0 International License, which permits unrestricted use, distribution, and reproduction in any medium, provided the original work is properly cited.

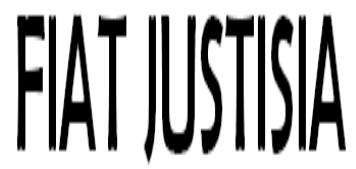

\title{
URGENSI PEMBENTUKAN UNDANG-UNDANG TENTANG ARBITRASE INTERNASIONAL
}

\section{The Urgency to Form Law on International Commercial Arbitration}

\author{
Huala Adolf \\ Fakultas Hukum Universitas Padjadjaran \\ email: hualaadolf@yahoo.com
}

\begin{abstract}
The Law No 30 of 1999 on Arbitration and Alternative Dispute Resolution contains provisions primarily on domestic arbitration. The provisions on international arbitration is scarce: it contains only 5 (five) articles which mostly regulate the international arbitration awards. This article suggested that Indonesia need a Law on International Commercial Arbitration.
\end{abstract}

Keywords: Law, International Arbitration

\begin{abstract}
Abstrak
UU Nomor 30 Tahun 1999 Tentang Arbitrase dan Alternatif Penyelesaian Sengketa memuat ketentuan-ketentuan yang sebagian besar mengenai arbitrase nasional. Ketentuan mengenai arbitrase internasional hanya ditemukan di dalam 5 (lima) pasalnya yaitu ketentuan mengenai putusan arbitrase internasional. Tulisan ini menyarankan agar Indonesia perlu segera membuat UU Arbitrase Internasional.
\end{abstract}

Kata Kunci: Undang-Undang, Arbitrase Internasional

\section{A. Pendahuluan}

Undang-Undang (UU) Nomor 30 Tahun 1999 tentang Artbitrase dan Alternatif Penyelesaian Sengketa adalah suatu produk hukum nasional RI yang penting di bidang arbitrase. ${ }^{1}$ UU ini lahir sewaktu RI sedang mengalami krisis moneter. Krisis yang lahir di tahun 1998 menyebabkan

\footnotetext{
${ }^{1}$ Lembaran Negara Republik Indonesia Tahun 1999 Nomor 138.
} 
cukup banyak dunia usaha mengalami kesulitan keuangan. Krisis ini telah pula melahirkan berbagai sengketa dagang yang sebagian besar karena tidak dipenuhinya kewajiban keuangan atau karena tidak dilaksanakannya kewajiban suatu pihak akibat terjadinya nilai tukar rupiah terhadap dollar yang tiba-tiba meningkat tinggi.

Data yang penulis peroleh, sengketa-sengketa akibat krisis moneter cukup banyak diserahkan kepada Badan Arbitrase Nasional Indonesia (BANI). Dalam upaya penyelesaian sengketa ini, UU diuji di dalam praktik. Hasil pengamatan yang penulis lakukan, penerapan UU ini untuk menyelesaikan sengketa dagang di antara pengusaha Indonesia oleh BANI umumnya dapat diterima dengan baik. Hal ini menunjukkan, ketentuan UU dapat mengakomodir kebutuhan dunia usaha di Indonesia untuk menyelesaikan sengketanya.

UU terdiri atas $11 \mathrm{Bab}, 82$ (delapan dua) pasal. Dari ketentuan pasalpasalnya, dapatlah kita amati bahwa sebagian besarnya mengatur pelaksanaan arbitrase di dalam negeri. Sebagian kecil ketentuan pasalnya mengatur arbitrase internasional. Bab VI bagian kedua berada di bawah judul "Arbitrase Internasional", memuat 5 (lima) pasal: Pasal 66 hingga Pasal 70.

Kelima pasal itu pun mengatur pelaksanaan putusan arbitrase internasional di Indonesia. Kelima pasal mengatur:

(1) kewenangan pengadilan dalam permohonan pelaksanaan putusan arbitrase asing (Pasal 65);

(2) syarat-syarat permohonan pelaksanaan putusan (Pasal 66),

(3) persyaratan pendaftaran putusan (Pasal 67),

(4) tertutupnya upaya banding terhadap putusan pengadilan negeri yang mengabulkan permohonan pelaksanaan putusan arbitrase asing (Pasal 68), dan

(5) kewenangan ketua pengadilan negeri untuk melaksanakan perintah eksekusi (Pasal 70).

Tulisan ini membahas, apakah pengaturan mengenai pelaksanaan arbitrase internasional cukup diatur di dalam ketentuan UU No 30 Tahun 1999? Atau, apakah perlu diatur secara khusus mengenai arbitrase internasional ini?

\section{B. Pembahasan}

\section{Pengertian Sistem Pemilihan dan Model Sistem Pemilihan}

a. Pendahuluan

UU Nomor 30 tahun 1999 mengandung sejumlah ketentuan-ketentuan yang khas mengenai arbitrase. Khas karena ketentuan di dalamnya mengandung ketentuan yang tidak terdapat di dalam ketentuan pasal-pasal atau UU mengenai arbitrase di berbagai negara di dunia. Kekhasan ini 
dapatlah disebut sebagai "kekuatan" UU ini. Kekhasan UU mencakup dua hal berikut.

Pertama, UU Arbitrase menentukan batas waktu proses arbitrase: majelis arbitrase atau arbiter diberi waktu selama 180 (seratus delapan puluh) hari sejak susunan majelis terbentuk untuk mengeluarkan putusannya (Pasal 48 UU). ${ }^{2}$

Penentuan jangka waktu 180 (seratus delapan puluh) hari cukup positif baik bagi majelis arbitrase maupun para pihak. Bagi majelis, adanya batas waktu ini mendorong mereka untuk segera memeriksa dan membuat putusan atas sengketa. Bagi para pihak, jangka waktu yang relatif singkat ini penting karena pada pandangan mereka, semakin cepat sengketa diselesaikan semakin baik bagi perusahaan.

Ketentuan perundang-undangan nasional di dunia termasuk UNCITRAL Model Law on International Commercial Arbitration (1985 dan Revisi 2006) tidak memuat jangka waktu ini. Bagi kalangan pengamat asing, jangka waktu waktu 180 hari untuk menyelesaikan sengketa adalah jangka waktu yang relatif pendek atau singkat. Biasanya, majelis arbitrase membutuhkan waktu sekitar antara 2 hingga 3 tahun untuk mengeluarkan putusannya.

Kedua, UU Arbitrase mewajibkan majelis arbitrase atau arbiter untuk terlebih dahulu mengupayakan penyelesaian sengketa melalui perdamaian. Pasal 45 UU menyatakan:

(1) Dalam hal para pihak datang menghadap pada hari yang telah ditetapkan, arbiter atau majelis arbitrase terlebih dahulu mengusahakan perdamaian antara para pihak yang bersengketa.

Dalam berbagai peraturan arbitrase di dunia, tidak ditemukan ketentuan seperti Pasal 45 ini. Tampaknya ketentuan pasal ini tidak terlepas dari pengaruh atau iklim penyelesaian sengketa damai (musyawarah untuk mufakat) yang telah dikenal lama. Semangat pasal ini juga mengedepankan perdamaian. Sifat seperti ini dapatlah dipandang sebagai kekuatan berarbitrase di Indonesia.

\section{b. Muatan UU}

UU mengatur secara komprehensif pelaksanaan arbitrase: mulai dari perjanjian arbitrase, sengketa yang dapat diarbitrasekan, pendaftaran atau permohonan arbitrase, syarat arbiter dan pembentukan majelis arbitrase, hingga pendaftaran, prosedur dan pelaksanaan putusan arbitrase, baik

\footnotetext{
${ }^{2}$ Meskipun dalam ayat 2 Pasal 48 ini dimungkinkan perpanjangan waktu dari batas waktu 180 hari ini.
} 
arbitrse nasional atau arbitrase internasional. Berikut uraian mengenai beberapa hal cukup penting yang termuat dalam UU.

\section{1) Perjanjian Arbitrase}

UU meletakkan sejumlah syarat yang harus dipenuhi untuk suatu perjanjian arbitrase. Pertama, perjanjian harus dalam bentuk tertulis. Kedua perjanjian harus ditandatangani oleh para pihak. ${ }^{3}$ Jika perjanjian dilakukan melalui telex, telegram, facsimile, email atau cara-cara lain, masing-masing pihak diwajibkan untuk membuat salinan penerimaan sebagai bukti bahwa perjanjian arbitrase telah disetujui.

Perjanjian arbitrase mengikat para pihak yang menandatanganinya. UU arbitrase secara jelas menentukan bahwa Pengadilan Negeri tidak memiliki kewenangan untuk menyelesaikan sengketa bila para pihak terikat perjanjian arbitrase. ${ }^{4}$

Ketentuan hukum ini telah lama dipraktikkan di Indonesia sebagaimana ditunjukkan dalam beberapa putusan Mahkamah Agung. Antara lain dalam putusan kasus PT. Metropolitan Timbers melawan PT Gaphi Trading $(19 / 6)^{5}$; PT. Baru Mulia Utama melawan Sainrapt et BriceSociete Auxiliare e'Enterprises/Societe Routiere Colas (1985) ${ }^{6}$; dan AHJU Forestry Company Ltd. melawan PT. Balapan Jaya (1987). ${ }^{7}$

\section{2) Sengketa Arbitrase}

Tidak semua sengketa dapat diselesaikan melalui arbitrase. Menurut UU Arbitrase sengketa yang dapat diselesaikan melalui arbitrase hanyalah sengketa dagang (Pasal 5). UU tidak memberi batasan pengertian atau ruang lingkup sengketa dagang. Praktik dan doktrin menunjukkan pengertian sengketa dagang diartikan secara luas, yaitu segala transaksi di bidang perdagangan. Termasuk dalam kategori ini adalah sengketa jual beli, sewa menyewa, leasing, usaha patungan, konstruksi, penanaman modal, dan lainlain. ${ }^{8}$

\footnotetext{
${ }^{3}$ Pasal 3 ayat (3) dan Pasal 4 ayat (2) UU Arbitrase

${ }^{4}$ Pasal 3 dan 7 ayat (2) UU Arbitrase

${ }^{5}$ Putusan Mahkamah Agung No 225 K/Sip/1976, tanggal 8 Februari 1982.

${ }^{6}$ Putusan Mahkamah Agung No 3992 K/Sip/1985 tanggal 4 Mei 1988.

${ }^{7}$ Putusan Mahkamah Agung No 2924/Sip/1981 tanggal 22 Februari 1982.

8 Lihat misalnya: Abdurrasyid, Priyatna. (2011). Arbitrase \& Alternatif Penyelesaian Sengketa (APS): Suatu Pengantar, ed.2. Jakarta: Fikahati Aneska, p. 3.
} 


\section{3) Syarat Arbiter}

UU Arbitrase tidak menentukan siapa yang dapat menjadi arbiter. Tetapi Pasal 12 UU Arbitrase menentukan beberapa persyaratan untuk menjadi arbiter. Persyaratan tersebut antara lain:

a) Memiliki kapasitas yang diakui oleh hukum Indonesia

b) Minimum berumur 35 tahun

c) Tidak memiliki hubungan apapun dengan para pihak, termasuk hubungan keluarga atau keuangan dan

d) Harus memiliki pengalaman selama 15 tahun di bidangnya.

UU Arbitrase menentukan bahwa hakim, jaksa, panitera dan pejabat peradilan lainnya tidak dapat ditunjuk atau diangkat sebagai arbiter (Pasal 12 ayat 2).

Persyaratan arbiter dalam Pasal 12 ayat 1 di atas tidaklah ditemukan di dalam UU negara lain. Tentang syarat ini, ada pertanyaan yang dilontarkan terhadap ketentuan pasal ini. Misalnya, bagaimana mengukur syarat nomor 2), yaitu minimum berusia 35 tahun. Apakah syarat minimum berumur 35 tahun ini tidak terlalu muda bagi seseorang untuk menjadi seorang arbiter? Begitu pula untuk syarat nomor 4), yaitu pengalamanan selama 15 tahun. Bagaimana atau kriteria apa yang digunakan untuk menentukan pengalaman selama 15 tahun ini.

\section{4) Hukum Acara Arbitrase}

Pada dasarnya para pihak memiliki kebebasan untuk memutuskan hukum acara arbitrase (Arbitration Rules). Jika tidak ditentukan para pihak, badan arbitrase dapat menentukannya. Umumnya, hukum acara yang akan diterapkan adalah hukum acara yang telah ada dalam lembaga arbitrase yang bersangkutan. ${ }^{9}$

Ketentuan lain dalam prosedur arbitrase yang digambarkan dalam UU, yakni:

a) Prosedur arbitrase harus dilakukan secara tertutup; ${ }^{10}$

\footnotetext{
${ }^{9}$ Lihat misalnya Pasal 1 Rules Arbitrase BANI.

"Apabila para pihak dalam suatu perjanjian atau transaksi bisnis secara tertulis sepakat membawa sengketa yang timbul diantara mereka sehubungan dengan perjanjian atau transaksi bisnis yang bersangkutan ke arbitrase di hadapan Badan Arbitrase Nasional Indonesia (BANI), atau menggunakan Peraturan Prosedur BANI, maka sengketa tersebut diselesaikan dibawah penyelenggaraan BANI berdasarkan Peraturan tersebut, dengan memperhatikan ketentuan-ketentuan khusus yang disepakati secara tertulis oleh para pihak, sepanjang tidak bertentangan dengan ketentuan undang-undang yang bersifat memaksa dan kebijaksanaan BANI. Penyelesaian sengketa secara damai melalui Arbitrase di BANI dilandasi itikad baik para pihak dengan berlandaskan tata cara kooperatif dan nonkonfrontatif."

${ }^{10}$ Pasal 27 UU Arbitrase.
} 
b) Bahasa yang digunakan dalam proses arbitrase adalah Bahasa Indonesia, kecuali apabila disepakati lain oleh para pihak $;{ }^{11}$

c) UU menjamin bahwa masing-masing pihak memiliki kesempatan dan hak yang sama untuk didengarkan dalam proses arbitrase, ${ }^{12}$

d) Pihak ketiga dapat ikut serta dalam arbitrase jika ia memiliki kepentingan dalam sengketa dan diijinkan oleh arbiter. ${ }^{13}$

\section{5) Putusan Provisionil (Sela)}

Pasal 32 menyatakan bahwa jika diminta salah satu pihak, majelis arbitrase dapat membut putusan provisionil termasuk, penyitaan atau pelelangan barang. Putusan ini dikeluarkan untuk memastikan ketertiban jalannya pemeriksaan sengketa. Pasal 32 ini menyatakan:

(1) Atas permohonan salah satu pihak, arbiter atau majelis arbitrase dapat mengambil putusan provisionil atau putusan sela lainnya untuk mengatur ketertiban jalannya pemeriksaan sengketa termasuk penetapan sita jaminan, memerintahkan penitipan barang kepada pihak ketiga, atau menjual barang yang mudah rusak.

(2) Jangka waktu pelaksanaan putusan provisionil atau putusan sela lainnya sebagaimana dimaksud dalam ayat (1) tidak dihitung dalam jangka waktu sebagaimana dimaksud dalam Pasal 48.

\section{6) Hukum Yang Berlaku}

Pasal 56 UU ini menyatakan bahwa para pihak dapat memutuskan hukum yang berlaku untuk suatu sengketa yang sedang atau akan terjadi. Namun apabila tidak ditentukan, arbiter harus menentukan hukum mana yang akan diberlakukan berdasarkan keadilan dan kepatutan. ${ }^{14}$

Dalam praktik, cukup sering ditemukan bahwa para pihak pun menghendaki majelis arbitrase memutus sengketanya berdasarkan pertimbangan keadilan. Permohonan seperti ini biasa disebut pula dengan penerapan keadilan (atau kepatutan) yang disebut dengan ex aequo et bono. Penerapan ex aequo et bono hanya dapat diperkenankan apabila para pihak (kedua pihak) dengan tegas menyatakan permohonannya ini.

\footnotetext{
${ }^{11}$ Pasal 28 UU Arbitrase.

${ }^{12}$ Pasal 29 UU Arbitrase.

${ }^{13}$ Pasal 30 UU Arbitrase.

${ }^{14}$ Prinsip ex aequo et bono (Pasal 56 UU Arbitrase).
} 


\section{7) Putusan Arbitrase}

Menurut Pasal 54 UU, putusan arbitrase harus memuat syarat-syarat sebagai berikut:

a) Kepala putusan berbunyi "DEMI KEADILAN BERDASARKAN KETUHANAN YANG MAHA ESA";

b) Nama lengkap dan alamat para pihak;

c) Deskripsi sengketa (pokok sengketa);

d) Pendirian para pihak;

e) Nama dan alamat arbiter;

f) Pertimbangan dan kesimpulan arbiter atau majelis arbitrase mengenai keseluruhan sengketa;

g) Pendapat tiap-tiap arbiter dalam hal terdapat perbedaan pendapat dalam majelis arbitrase;

h) Amar putusan;

i) Tempat dan tanggal putusan dikeluarkan;

j) Tanda tangan arbiter atau majelis arbitrase.

UU menyaratkan bahwa putusan harus ditandantangani oleh semua arbiter. Ketiadaan tanda tangan arbiter, karena sakit atau meninggal dunia tidak mempunyai pengaruh kekuatan mengikat hukum suatu putusan. Namun alasan ketiadaan tanda tangan harus disebutkan dalam putusan. Putusan harus menyebutkan di mana atau batas waktu putusan harus dilaksanakan.

Komentar umum yang dikemukakan oleh para pengamat atau praktisi arbitrase (asing) adalah syarat (a) di atas yaitu adanya irah-irah berbunyi: "Demi Keadilan Berdasarkan Ketuhanan Yang Maha Esa." Persoalannya adalah adanya irah-irah ini tidak ada dan tidak disyaratkan dalam putusan arbitrase di mana pun juga. Kekhasan ini mungkin hanya ada di Indonesia.

Sepengetahuan penulis, irah-irah ini penting dicantumkan dalam suatu putusan yang sifatnya "judisial". Irah-irah ini merupakan syarat yang harus ada dalam setiap putusan pengadilan agar dapat memperoleh kekuatan eksekutorial seperti halnya suatu putusan pengadilan.

Selanjutnya, komentar lain yang dilontarkan adalah bunyi "Ketuhanan Yang Maha Esa." Bagi kita, dapatlah dimaklumi pengertian ini karena pandangan hidup bangsa yang tercantum dalam sila pertama Pancasila. Namun bagi pengamat atau praktisi asing, persyaratan ini dipandang agak janggal. $^{15}$

${ }^{15}$ Ketua BANI, Husseyn Umar, pernah mengungkapkan hal ini dalam suatu percakapan di sekitar tahun 2014-2015. Beliau melontarkan pertanyaan pihak asing terhadap irah-irah ini, yaitu Tuhan yang mana yang dimaksud dalam irah-irah itu? 


\section{8) Pelaksanaan Putusan}

a) Arbitrase Nasional

Dalam kaitannya mengenai putusan yang dapat dilakukan, putusan tersebut harus dilaksanakan dalam waktu 30 hari sejak putusan dikeluarkan. Putusan arbitase yang asli harus dilampirkan dan didaftarkan ke panitera pengadilan negeri di mana Termohon berdomisili.

Arbiter atau kuasa para pihak harus menyertakan juga putusan dan surat penunjukan asli dirinya sebagai arbiter atau salinan yang dilegalisir kepada panitera pengadilan negeri. Kesalahan dalam memenuhi persyaratan ini akan membuat putusan tidak dapat dilaksanakan ('null and void').

Salah satu pihak dapat mengajukan permohonan kepada ketua pengadilan negeri untuk melaksanakan putusan. Perintah eksekusi harus dibuat dalam waktu 30 hari sejak permohonan didaftarkan di pengadilan negeri.

Sebelum memberikan perintah, ketua pengadilan negeri harus menguji apakah putusan tersebut tidak bertentangan dengan moral atau ketertiban umum. Jika bertentangan, ketua pengadilan negeri harus menolak perintah eksekusi, dan tidak ada banding untuk putusan tersebut.

Ketua pengadilan negeri boleh menguji alasan hukum arbiter. Perintah ketua pengadilan negeri harus ditulis dalam dokumen otentik (resmi) atau salinan putusan arbitrase yang disahkan. Perintah tersebut harus dieksekusi dengan cara sebagaimana ditentukan oleh pengadilan negeri.

\section{b) Arbitrase Internasional}

Menurut Pasal 65, pengadilan negeri Jakarta Pusat adalah satu-satunya pengadilan yang memiliki kewenangan untuk menangani persoalan tentang pengakuan dan pelaksanaan putusan arbitrase internasional (asing).

Dalam UU arbitrase, putusan arbitrase internasional dilaksanakan di Indonesia, jika:

a) Negara di mana putusan arbitrase dibuat juga menjadi anggota perjanjian bilateral atau multilateral dengan Indonesia tentang Pengakuan dan Pelaksanaan Putusan Arbitrase Asing.

b) Putusan tersebut haruslah mengenai bidang hukum dagang menurut hukum Indonesia;

c) Putusan tersebut tidak bertentangan dengan ketertiban umum;

d) Putusan tersebut dapat dilaksanakan hanya jika telah mendapat perintah eksekusi dari ketua pengadilan negeri Jakarta Pusat. ${ }^{16}$

\footnotetext{
${ }^{16}$ Pasal 66 UU Arbitrase. Ketentuan ini sesuai dengan reservasi Indonesia terhadap Konvensi New York 1958 dan Surat Edaran MA No 1 tahun 1990 tentang Pelaksanaan putusan arbitrase asing.
} 
Jika salah satu pihak adalah negara Indonesia, maka putusan itu harus dilaksanakan berdasarkan perintah eksekusi dari Mahkamah Agung. Perintah eksekusi kemudian digunakan oleh Pengadilan Negeri Jakarta Pusat untuk melaksankaan putusan arbitrase.

Itu juga berarti bahwa permintaan pelaksanaan putusan arbitrase asing hanya akan dilaksanakan hanya setelah putusan arbitrase itu didaftarkan di Panitera Pengadilan Negeri Jakarta Pusat.

Permohonan pelaksanaan putusan harus dilampirkan dengan:

a) Putusan asli (otentik) atau salinan putusan yang telah dilegalisir dan diterjemahkan resmi dalam bahasa Indonesia;

b) Dokumen resmi atau salinan dokumen perjanjian arbitrase dan diterjemahkan resmi dalam bahasa Indonesia;

c) Pernyataaan dari perwakilan diplomatik Indonesia di negara di mana putusan itu dibuat bahwa permohonan pihak yang mengajukan terikat secara bilateral atau multilateral terhadap pengakuan dan pelaksanaan putusan asing di mana Indonesia juga merupakan pihak (peserta). ${ }^{17}$

Dari uraian di atas, tampak bahwa ketentuan-ketentuan di atas berbeda dengan ketentuan yang ada atau dikenal dalam masyarakat umumnya. Hal ini menurut penulis menunjukkan atau memperkuat asumsi bahwa pertama, memang UU Nomor 30 Tahun 1999 memuat ketentuan arbitrase yang sifatnya nasional atau domestik.

Kedua, persyaratan dalam UU yang mensyaratkan adanya "Pernyataan dari perwakilan diplomatik Indonesia di negara di mana putusan dibuat" adalah persyaratan yang dianggap cukup memberatkan. Dalam berbagai seminar mengenai hukum arbitrase Indonesia, persyaratan ini dianggap membebani suatu pihak yang menang, suatu syarat yang seharusnya tidak perlu ada. ${ }^{18}$

Ketiga, asumsi ini diperkuat dengan adanya ketentuan mengenai pelaksanaan putusan arbitrase internasional (dalam Pasal 66 hingga 70). Dalam bagian ini UU secara spesifik menyantumkan kata internasional untuk menunjukkan suatu putusan arbitrase internasional (bukan domestik).

17 Pernyataan tersebut sifatnya adalah memaksa menurut hukum Indonesia, meskipun Konvensi New York 1958 tidak menentukan demikian.

${ }^{18}$. Pasal III Konvensi New York 1958 melarang suatu Negara untuk meletakkan syarat yang memberatkan di dalam suatu pihak memohon pelaksanaan putusan arbitrase di suatu Negara. Pasal ini menyatakan:

"Each Contracting State shall recognize arbitral awards as binding and enforce them in accordance with the rules of procedure of the territory where the award is relied upon, under the conditions laid down in the following articles. There shall not be imposed substantially more onerous conditions or higher fees or charges on the recognition or enforcement of arbitral awards to which this Convention applies than are imposed on the recognition or enforcement of domestic arbitral awards." (Cetak miring oleh penulis). 
Hal ini juga menunjukkan bahwa UU ini memberi petunjuk mana ketentuan domestik, meski tidak dicantumkan secara eksplisit, dan mana yang internasional (karena dicantumkan secara tegas).

\section{UU dalam Praktik}

\section{a. Batasan Arbitrase Internasional}

Satu hal yang menarik perhatian dari UU Nomor 30 tahun 1999 ini adalah bahwa UU tidak memberi batasan secara khusus arti arbitrase internasional. UU hanya memberi batasan putusan arbitrase internasional. Menurut Pasal 1 angka 9 terdapat dua alternatif pengertian putusan arbitrase internasional:

"Putusan Arbitrase Internasional adalah putusan yang dijatuhkan oleh suatu lembaga arbitrase atau arbiter perorangan di luar wilayah hukum Republik Indonesia, atau putusan suatu lembaga arbitrase atau arbiter perorangan yang menurut ketentuan hukum Republik Indonesia dianggap sebagai suatu putusan arbitrase internasional."

Dari pengertian itu dapat ditarik kesimpulan terdapat 2 (dua) pengertian alternatif terhadap putusan arbitrase internasional, yaitu:

1) Putusan arbitrase yang dibuat oleh suatu lembaga arbitrase atau arbiter perorangan di luar wilayah hukum Republik Indonesia; atau;

2) Putusan suatu lembaga arbitrase atau arbiter perorangan yang menurut ketentuan hukum Republik Indonesia dianggap sebagai suatu putusan arbitrase internasional.

Permasalahan timbul mengenai alternatif kedua. Alternatif pertama cukup jelas, yaitu putusan arbitrase (yang terlembaga atau $a d$ hoc) sepanjang dibuat di luar wilayah hukum Indonesia. Sedangkan alternatif kedua, "yang menurut ketentuan hukum Republik Indonesia dianggap sebagai suatu putusan arbitrase internasional" sangat potensial menimbulkan multiinterpretasi. Permasalahannya adalah hukum Republik Indonesia apa atau yang mana tidak secara jelas disebutkan. Dalam penjelasan ketentuan pasal ini hanya disebutkan bahwa pengertian pasal ini sudahlah jelas.

\section{b. Sengketa Acuan: PT Lirik melawan PT Pertamina}

Dalam sengketa sekarang ini, PT Lirik Petroleum adalah sebuah perusahaan swasta nasional yang bergerak di bidang perminyakan. Sedangkan PT Pertamina adalah suatu BUMN yang bergerak di bidang perminyakan. Kedua pihak menandatangani suatu perjanjian berjudul the Enhanced Oil Recovery (EOR) Contract pada tanggal 29 Maret 1991.

Perjanjian dibuat dalam bahasa Inggris. Mata uang yang digunakan adalah dollar AS. Hukum yang berlaku (dipilih oleh para pihak) adalah 
hukum RI. Forum penyelesaian sengketa yang dipilih adalah arbitrase menurut hukum acara badan arbitrase internasional ICC (International Chamber of Commerce). Tempat arbitrase adalah Jakarta.

Sengketa kemudian timbul sehubungan dengan pelaksanaan perjanjian EOR. Badan arbitrase ICC dibentuk untuk menangani sengketa. Arbiter untuk Majelis Arbitrase terdiri atas dua orang (WN) Indonesia dan seorang warga asing.

Dalam putusannya, Majelis Arbitrase memutuskan bahwa Pertamina telah melanggar kontrak (perjanjian). Majelis memerintahkan Pertamina untuk membayar ganti rugi. ${ }^{19}$ Pertamina mengajukan banding ke Pengadilan Negeri Jakarta Pusat. Pertamina memohon pembatalan putusan arbitrase internasional ICC.

Salah satu masalah yang terangkat dalam kaitannya dengan putusan arbitrase ICC adalah apakah putusan arbitrase internasional ICC yang dibuat di Jakarta dapat dianggap sebagai arbitrase domestik (dalam negeri)?

Pertamina berpendapat, karena arbitrase dilangsungkan di Indonesia, maka menurut UU RI, putusan tersebut adalah putusan domestik. Karena itu, putusannya pun harus dianggap atau dipandang sebagai putusan arbitrase nasional. Dasar hukum Pertamina untuk mendukung dalilnya adalah Pasal 1 (9) UU Nomor 30 Tahun 1999.

Sebagai suatu putusan arbitrase domestik (nasional), putusan tersebut telah melanggar persyaratan pendaftaran. Pendaftaran putusan arbitrase harus dilaksanakan tidak lebih dari 30 hari sejak putusan diberikan atau ditandatangani sesuai dengan ketentuan Pasal 59 UU Nomor 30 Tahun 1999.

Pihak PT Lirik Petroleum menolak dalil Pertamina. PT Lirik berpendapat, putusan arbitrase dalam sengketa ini memperlihatkan aspekaspek internasional dari suatu putusan. Menurut PT Lirik, untuk menentukan apakah suatu putusan arbitrase adalah putusan arbitrase internasional harus dipertimbangkan adanya hubungan yang terkait dengan arbitrase, yaitu:

1) Pilihan forum yaitu forum arbitrase ICC yang tunduk pada aturan arbitrase ICC yang telah para pihak sepakati;

2) Mata uang yang digunakan dalam kontrak adalah mata uang dollar AS;

3) Ketika menandatangani perjanjian EOR antara Pertamina dan PT Lirik pada tahun 1991 di Indonesia, Pertamina sejak semula telah bermaksud menggunakan lembaga arbitrase yang bukan badan arbitrase nasional

Pengadilan Negeri Jakarta Pusat dalam putusannya menyatakan bahwa putusan badan arbitrase ICC yang dibuat di Indonesia adalah suatu putusan arbitrase internasional. Karena itu, meskipun majelis arbitrase dilaksanakan di wilayah Indonesia, putusan tersebut harus dipandang sebagai suatu putusan arbitrase internasional.

\footnotetext{
${ }^{19}$ Award of the ICC Arbitration No. 14387/JB/JEM.
} 

berikut:

Dalam pertimbangannya, Pengadilan Negeri mengemukakan hal-hal

1) Sejak semula para pihak telah sepakat bahwa sengketa mereka akan diselesaikan oleh badan arbitrase ICC yang akan dilaksanakan di Jakarta sesuai dengan Bagian XII Perjanjian EOR;

2) Bahwa sengketa para pihak telah diselesaikan oleh Majelis Arbitrase ICC yang putusannya dibuat pada tanggal 22 September 2008 (Putusan Sebagian atau partial award) dan 27 Februari 2009 (Putusan Akhir);

3) Bahwa putusan arbitrase ICC telah didaftarkan pada Pengadilan Negeri Jakarta Pusat pada tanggal 21 April 2009.

Atas dasar fakta-fakta tersebut, Pengadilan Negeri Jakarta Pusat berpendapat bahwa pihak pemohon pembatalan putusan (Pertamina) sejak awal sudah menyadari bahwa ketika perjanjian ditandatangani, pemohon telah menyadari bahwa Majelis Arbitrase ICC adalah sebuah lembaga arbitrase internasional. Pengadilan Negeri juga berpendapat bahwa pemohon telah sepakat untuk menerapkan aturan arbitrase ICC. Karena itu pengadilan negeri berpendapat bahwa putusan arbitrase ICC adalah suatu putusan arbitrase internasional.

Seperti tampak dalam pertimbangannya, pengadilan negeri tidak menyandarkan secara verbatim pengertian putusan arbitrase internasional sesuai dengan Pasal 1 angka (9) UU Nomor 30 Tahun 1999, yaitu suatu pendekatan yang menggunakan wilayah negara (Indonesia) sebagai kriteria untuk menentukan suatu putusan sebagai putusan arbitrase internasional yaitu putusan yang dibuat di luar wilayah Indonesia.

Terhadap putusan Pengadilan Negeri, Pemohon mengajukan kasasi ke Mahkamah Agung. Dalam putusannya Mahkamah Agung menguatkan putusan PN.

Sengketa PT Lirik melawan PT Pertamina menggambarkan bagaimana ketentuan atau pengertian putusan arbitrase internasional menimbulkan permasalahan di Indonesia. Hal ini disebabkan karena pendekatan yang ditempuh oleh UU Nomor 30 tahun 1999 menggunakan kriteria tempat, bukan menggunakan kriteria yang telah umum diterima masyarakat internasional sebagaimana yang termuat di dalam UNCITRAL Model Law on International Commercial Arbitration.

Di samping itu, UU No. 30 tahun 1999 ini kurang atau tidak mengatur aspek-aspek yang mengatur arbitrase internasional yang penyelenggaraannya dilaksanakan di Indonesia.

Dampak atau implikasi dari tidak lengakapnya atau kurangnya pengaturan mengenai arbitrase internasional adalah timbulnya keengganan terhadap pihak asing (investor atau pelaku perdagangan internasional) untuk menyelesaikan sengketanya melalui arbitrase di Indonesia. Mereka tidak mau terulang kembali permasalahan mengenai terhalangnya pelaksanaan 
putusan arbitrase seperti tampak dalam sengketa PT Lirik melawan PT Pertamina di atas semata-mata karena putusan dibuat di Indonesia. Di kalangan dunia arbitrase, cukup banyak pengamat yang memandang Indonesia sebagai negara yang 'unfriendly' (tidak ramah) terhadap arbitrase.

Putusan MA sudah tepat mengenai pengertian putusan arbitrase internasional. Sampai sejauh mana putusan ini akan diikuti oleh pengadilanpengadilan selanjutnya masih perlu dibuktikan dalam praktik. Namun demikian, akan jauh lebih baik apabila rumusan Pasal 1 angka (9) tersebut direvisi sesuai dengan kriteria yang umum berlaku. Dengan revisi ini permasalahan mengenai penafsiran terhadap pengertian putusan arbitrase internasional dapat dihindari.

\section{Mengapa Perlu UU Arbitrase Internasional a. Pengantar}

Dari uraian di atas tampak bahwa UU memiliki ketentuan khas. Dari fakta ini tampak bahwa muata UU ini tidak mengikuti ketentuan yang diterima umum dalam masyarakat arbitrase internasional. Pedoman yang digunakan dewasa ini adalah UNCITRAL Model Law on International Commercial Arbitration 1985.

Di samping UU tersebut, perlu pula dikemukakan bahwa Indonesia terikat oleh New York Convention on the Recognition and Enforcement of Foreign Arbitral Awards of 1958 (Konvensi New York 1958) sebagaimana telah diratifikasi dengan Keputusan Presiden No. 34 Tahun 1981. Indonesia juga merupakan anggota Washington Convention on the Settlement of Investment Disputes between States and National of Other States of 1965 diratifikasi dengan UU No 5 Tahun $1968 .^{20}$

\section{b. Alasan UNCITRAL Model Law on International Commercial Arbitration}

Sudah diakui umum bahwa UU arbitrase internasional mengacu atau berkiblat kepada UNCITRAL Model Law mengenai Arbitrase Internasional

\footnotetext{
${ }^{20}$ Keppres No. 34 Tahun 1981 hanya memuat pasal-pasal yang menyatakan bahwa RI terikat oleh Konvensi New York. Di dalam pelaksanaannya, muatan Konvensi atau bahkan terjemahan mengenai muatan Konvensi tidak pernah dilakukan sampai sekarang. Karena itulah, konvensi yang penting ini yaitu pengakuan dan pelaksanaan putusan arbitrase asing, acapkali menemui permasalahan khususnya ketika lahir permohonan dari pihak asing kepada pengadilan RI untuk melaksanakan putusan arbitrase asing. Masalahnya adalah, di dalam melaksanakan pekerjaannya, hakim biasanya menyandarkan dirinya kepada aturanaturan hukum tertulis yang berlaku menurut hukum Indonesia, yaitu ketentuan hukum perundang-undangan positif. Selama Konvensi belum diterjemahkan dan diundangkan sebagai UU, sulit bagi pengadilan untuk menyandarkan pada pekerjaannya pada Konvensi ini.
} 
(Model Law). Model Law dirancang berdasarkan diskusi ekstensif di antara para ahli arbitrase ternama. Hasil rumusan ketentuannya telah pula disertai dengan konsultasi dengan berbagai lembaga arbitrase internasional di dunia.

Adalah badan kelengkapan utama PBB, yaitu Majelis Umum (General Assembly) yang mengesahkan UNCITRAL Model Law mengenai Arbitrase Komersial (Dagang) Internasional. Ketika mengesahkan Model Law ini dalam Resolusi Nomor 40/72 tanggal 11 Desember 1985, Majelis Umum menyatakan beberapa hal berikut:

1) Negara-negara anggota PBB menyadari arti penting arbitrase sebagai suatu metode penyelesaian sengketa di bidang perdagangan internasional;

2) Menyadari bahwa pembentukan suatu Model Law (Model atau acuan perundang-undangan) lebih mudah diterima negara-negara di dunia yang memiliki sistem hukum, sosial dan ekonomi yang berbeda-beda guna terciptanya suatu hubungan ekonomi internasional yang harmonis;

3) Menimbang bahwa UNCITRAL telah membuat Model Law mengenai Arbitrase Perdagangan Internasional ini pada sidangnya yang ke-18 setelah mengadakan konsultasi dan pembahasan yang ekstensif dengan berbagai lembaga arbitrase di dunia dan dengan para pakar arbitrase di dunia;

4) Berkeyakinan bahwa Model Law beserta Konvensi mengenai Pengakuan dan Pelaksanaan Putusan Arbitrase Asing (Konvensi New York 1958) dan Aturan Arbitrase yang kemudian disahkan oleh Majelis Umum PBB adalah sumbangan berharga bagi terciptanya suatu kerangka hukum untuk tercapainya penyelesaian sengketa perdagangan internasional yang adil dan efisien.

5) Meminta kepada Sekretaris Jenderal PBB untuk menyebarluaskan teks pasal-pasal Model Law Arbitrase Perdagangan Internasional kepada seluruh negara anggota PBB;

6) Menganjurkan kepada semua negara untuk mempertimbangkan Model Law mengenai Arbitrase Perdagangan Internasional karena (telah) terdapatnya keseragaman pengaturan mengenai hukum arbitrase dan adanya kebutuhan khusus praktik arbitrase perdagangan internasional. (Cetak miring oleh kami).

Sebanyak 71 negara (dengan 101 Jurisdiksi) telah mengadopsi UNCITRAL Model Law on International Comemrcial Arbitration. Ke-71 negara ini termasuk negara maju maupun negara berkembang. Negara maju, antara lain: Australia, Austria, Belgia, Jepang, Jerman, Norwegia, Selandia Baru, Inggris, Amerika Serikat. Sedangkan negara berkembang yang 
mengadopsi UNCITRAL Model Law antara lain adalah Bhutan, Bangladesh, Iran, India, Mesir, Nigeria, Sri Lanka, Turki, Zambia, Zimbabwe, dll. ${ }^{21}$

Di ke-10 negara anggota ASEAN, hanya 6 (enam) negara telah mengadopsi UNCITRAL Model Law on International Commercial Arbitration ke dalam peraturan perundang-undangannya adalah: 1) Brunei Darussalam, 2) Filipina, 3) kamboja, 4) Malaysia 5) Singapura, 6) Thailand. ${ }^{22}$ Negara anggota ASEAN yang tidak atau belum mengadopsi adalah Indonesia, Laos, Myanmar dan Vietnam.

\section{Penutup \\ 1. Simpulan}

Bardasarkan uraian tulisan di atas, dapat ditarik kesimpulan analisa di atas tampak bahwa:

a. Dalam peraturan perundang-undangan nasional, arbitrase mendapat pengaturan yang khusus yang pelaksanaannya harus dituangkan ke dalam bentuk UU.

b. Kajian terhadap UU Nomor 30 tahun 1999 mengenai arbitrase internasional menunjukkan bahwa dengan status pengaturan sekarang secara teknis yuridis formal, setiap putusan arbitrase yang dibuat di dalam wilayah Indonesia, sedikit banyak akan kesulitan untuk mendapatkan eksekusi atau pelaksanaan putusannya di luar negeri.

\section{Saran}

a. Dari analisis di atas, tampak bahwa Indonesia saat ini sangat membutuhkan suatu peraturan khusus mengenai arbitrase internasional. Kehadiran suatu undang-undang khusus akan memberi kenyamanan pihak asing untuk menyelesaikan sengketanya di Indonesia.

b. Pemerintah perlu segera mengadopsi UNCITRAL Model Law on International Commercial Arbitration ke dalam peraturan perundangundangan RI yang khusus mengatur arbitrase internasional di Indonesia.

\section{Daftar Pustaka}

\section{A. Buku}

Abdurrasyid, Priyatna. (2011). Arbitrase \& Alternatif Penyelesaian Sengketa (APS): Suatu Pengantar, ed.2. Jakarta: Fikahati Aneska

\footnotetext{
${ }^{21} \mathrm{http}: / /$ www.uncitral.org/uncitral/en/uncitral_texts/arbitration/1985Model_arbitration_status. html.

${ }^{22} \mathrm{Ibid}$
} 
Cheng, Chia-Jui. (1986). Basic Documents on International Trade Law, Martinus Nijhoff Publishers.

David, Rene. (1985). Arbitration in international Trade, Netherlands: Kluwer.

Doore, Isaak I, (1986). Arbitration and Conciliation under the UNCITRAL Rules: A Textual Analysis, Boston: Martinus Nijhoff Publishers.

Elkouri, Frank dan Edna Asper Elkouri, (1982). How Arbitration Works, Washington D.C.: The Bureau of National Affairs, Inc., 2d.ed.

Adolf, Huala. (1993). Arbitrase Komersial Internasional, Jakarta: Rajawali Pers, cet. 2.

Kusumaatmadja, Mochtar dan Agoes, Etty R. (2003). Pengantar Hukum Internasional, Bandung: Alumni.

Oehmke, Thomas, (1987). Commercial Arbitration, the Lawyer Cooperative Publishers Co.

Redfern, Alan dan Hunter, Martin. (1986). Law and Practice of International Commercial Arbitration, London: Sweet and Maxwell.

Rubino-Sammartano, Mauro. (1990). International Arbitration Law, Kluwer. Sanders, Pieter (General Editor). (1984). International Handbook on Commercial Arbitration, National Reports: Basic Legal Texts, International Council for Commercial Arbitration, The Netherlands: Kluwer,- sekarang (diperbaharui setiap tahun).

(1992). International Law Handbook on Commercial Arbitration (Deventer: Kluwer Law and Taxation Publishers.

Sudargo, Gautama. (1975). Kontrak Dagang Internasional (Himpunan Ceramah dan Prasaran), Bandung: Alumni.

UN Secretary General. (1966). Steps to be Taken for the Promoting the Harmonisation and Unification of the Law of International Commercial Arbitration: Report of the Secretary General of the United Nations.

UNCITRAL Secretariat, Explanatory Note by the UNCITRAL secretariat on the 1985 Model Law on International Commercial Arbitration as amended in 2006.

\section{B. Peraturan Perundang-Undangan}

\section{UUD 1945}

UU Nomor 5 Tahun 1968 Tentang Penyelesaian Perselisihan antara Negara dan Warganegara Asing mengenai Penanaman Modal

UU Nomor 30 Tahun 1999 tentang Arbitrase dan Alternaif Penyelesaian Sengketa

UU Nomor 48 Tahun 2009 tentang Kehakiman

UU Nomor 12 Tahun 2011 Tentang Pembentukan Peraturan Perundangundangan 
Keputusan Presiden Nomor 34 tahun 1981 tentang Pengesahan Mengesahkan "Convention on the Recognition and Enforcement of ForeignArbitral Awards."

Peraturan Mahkamah Agung Republik Indonesia Nomor 1 Tahun 1990 tentang Tata Cara Pelaksanaan Putusan Arbitrase Asing

Surat Edaran MA No 1 tahun 1990 tentang Pelaksnaan Putusan Arbitrase Asing

\section{Sumber Lain}

http://www.uncitral.org/uncitral/en/uncitral_texts/arbitration/1985Model_ arbitration_status.html.

Award of the ICC Arbitration No. 14387/JB/JEM.

Konvensi New York 1958.

Putusan Mahkamah Agung No 225 K/Sip/1976, tanggal 8 Februari 1982. Putusan Mahkamah Agung No 3992 K/Sip/1985 tanggal 4 Mei 1988.

Putusan Mahkamah Agung No 2924/Sip/1981 tanggal 22 Februari 1982. Kantaatmadja, Komar. (1989). Beberapa Hal Tentang Arbitrase, Kertas Kerja pada Penataran Hukum Ekonomi Internasional Fakultas Hukum Universitas Padjadjaran-Universitas Utrecht. 
